Article

\title{
Expression and Characterization of an Alginate Lyase and Its Thermostable Mutant in Pichia pastoris
}

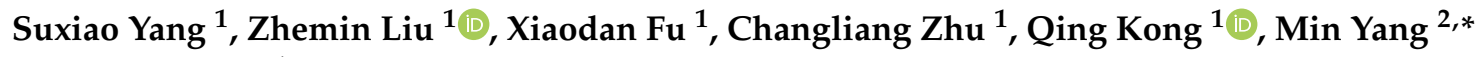 \\ and Haijin Mou ${ }^{1, *}$ \\ 1 College of Food Science and Engineering, Ocean University of China, Qingdao 266003, China; \\ yangsuxiao66@163.com (S.Y.); ocean2013@126.com (Z.L.); luna_9303@163.com (X.F.); \\ chlzhu@163.com (C.Z.); kongqing@ouc.edu.cn (Q.K.) \\ 2 Yellow Sea Fisheries Research Institute, Chinese Academy of Fishery Sciences, Laboratory for Marine Drugs \\ and Bioproducts of Pilot National laboratory for Marine Science and Technology, Qingdao 266071, China \\ * Correspondence: yangmin@ysfri.ac.cn (M.Y.); mousun@ouc.edu.cn (H.M.); \\ Tel./Fax: +86-532-85802889 (M.Y.); +86-532-82032290 (H.M.)
}

Received: 27 April 2020; Accepted: 8 June 2020; Published: 11 June 2020

check for updates

\begin{abstract}
Alginate is one of the most abundant polysaccharides in algae. Alginate lyase degrades alginate through a $\beta$-elimination mechanism to produce alginate oligosaccharides with special bioactivities. Improving enzyme activity and thermal stability can promote the application of alginate lyase in the industrial preparation of alginate oligosaccharides. In this study, the recombinant alginate lyase cAlyM and its thermostable mutant 102C $300 \mathrm{C}$ were expressed and characterized in Pichia pastoris. The specific activities of cAlyM and 102C300C were $277.1 \mathrm{U} / \mathrm{mg}$ and $249.6 \mathrm{U} / \mathrm{mg}$, respectively. Both enzymes showed maximal activity at $50{ }^{\circ} \mathrm{C}$ and $\mathrm{pH} 8.0$ and polyG preference. The half-life values of $102 \mathrm{C} 300 \mathrm{C}$ at $45^{\circ} \mathrm{C}$ and $50{ }^{\circ} \mathrm{C}$ were 2.6 times and 11.7 times the values of cAlyM, respectively. The degradation products of $102 \mathrm{C} 300 \mathrm{C}$ with a lower degree of polymerization contained more guluronate. The oligosaccharides with a polymerization degree of $2-4$ were the final hydrolytic products. Therefore, $102 \mathrm{C} 300 \mathrm{C}$ is potentially valuable in the production of alginate oligosaccharides with specific $\mathrm{M} / \mathrm{G}$ ratio and molecular weights.
\end{abstract}

Keywords: Pichia pastoris; alginate lyase; thermostable mutant; alginate oligosaccharides

\section{Introduction}

Alginate is a natural anionic polysaccharide and one of the main structural components of brown algae, accounting for approximately $40 \%$ of the algal dry weight [1]. Structurally, alginate is an unbranched binary copolymer comprised of $\beta$-D-mannuronate $(\mathrm{M})$ and $\alpha$-L-guluronate $(\mathrm{G})$ units. These units appear in three types of blocks: poly $\beta$-D-mannuronate (polyM), poly $\alpha$-L-guluronate (polyG), and a heteropolymer (polyMG). As an abundant marine biomass and inexpensive material, alginate has been used in many fields, predominantly in the textile, cosmetic, food, and medical industries [2-4].

The biological activity of alginate oligosaccharides (AOS), comprised of alginate oligomers containing 2 to 25 monomers, has been recognized. AOS is exploited in food, medicine, and agriculture. AOS has antioxidant, anti-inflammatory, prebiotic, and antibacterial activities, among others, with the $\mathrm{M} / \mathrm{G}$ ratio and molecular weight playing important roles in its potential bioactivity [5]. AOS with a low $\mathrm{M} / \mathrm{G}$ ratio was reported to inhibit the pancreatic lipase [6]. AOS with a polymerization degree of 3-6 can induce cytokine synthesis [7], and AOS with a polymerization degree of 2-10 significantly inhibits the growth of human prostate cancer cells [8]. Furthermore, as a derivative of alginate oligosaccharides, propylene glycol alginate sodium sulfate (PSS) which is a heparinoid drug can prevent 
and treat hyperlipidemia and ischemic cardio-cerebrovascular diseases [9]. Oligomannuronic acid with two carboxyl groups at the reducing end (GV-971) reportedly improves cognition in patients with Alzheimer's disease (AD) [10].

Alginate lyase can cleave alginate glycosidic bonds via a $\beta$-elimination mechanism, some of which have been isolated from algae, marine invertebrates and microorganisms [11,12]. Based on substrate specificity, alginate lyase can be classified into polyG lyases (EC 4.2.2.11), polyM lyases (EC 4.2.2.3), and polyMG lyases (EC 4.2.2.-). Due to the yield of alginate lyase in wild microorganism is low, heterologous expression is used to express alginate lyase. Some alginate lyases have been successfully expressed in E. coli [13-16]. We previously reported that an alginate lyase cAlyM with high enzymatic activity from Microbulbifer sp. Q7 (CGMCC 14061) expressed in E. coli [17]. However, E. coli is unable to secrete recombinant protein into the medium, and the application of the recombinant protein produced by $E$. coli is limited due to the safety of residual endotoxin.

Compared with E. coli, P. pastoris can secrete recombinant protein into the medium as soluble form, so it can be used to produce large quantities of enzymes by high-density fermentation without complicated purification steps [18]. P. pastoris expression system has significant advantages in the production of many recombinant proteins [19], but there are few reports of alginate lyases expressed in P. pastoris [20]. Moreover, due to the low activity and poor thermal stability of alginate lyases, their applications in the production of AOS have been limited [21]. Previous research on thermostable mutants of cAlyM in our laboratory has demonstrated that a thermostable mutant 102C300C, which has an additional disulfide bond expressed in E. coli, has good thermal stability, with the half-life value at $45^{\circ} \mathrm{C}$ that is 2.18 times that of cAlyM [22].

To obtain a safe alginate lyase with high enzymatic activity and good thermal stability, the alginate lyase cAlyM and its thermostable mutant $102 \mathrm{C} 300 \mathrm{C}$ were expressed in P. pastoris, and the enzymatic properties of these two enzymes were characterized and compared in detail. The degradation products were analyzed by high performance liquid chromatography (HPLC) and electrospray ionization mass spectrometry (ESI-MS).

\section{Results and Discussion}

\subsection{Recombinant Expression of cAlyM and $102 C 300 C$}

Due to the difference in codon usage bias between P. pastoris and wild microorganisms, the presence of rare codons in foreign genes reduced the expression level of recombinant proteins in the host. After optimization according to P. pastoris codon usage bias, foreign genes might reduce the diversity of tRNA and increase the expression level [18]. The non-optimized gene consisting of $951 \mathrm{bp}$ from Microbulbifer sp. Q7 (CGMCC 14061) was optimized. The similarity between the non-optimized gene and optimized gene was $73.5 \%$.

In a previous study, the half-life value of the mutant 102C300C expressed in E. coli was 2.18 times that of cAlyM [22]. Therefore, to improve the thermal stability of the recombinant enzyme expressed in P. pastoris, an additional disulfide bond was introduced into cAlyM by site-directed mutagenesis. The aspartate acid (D) at position 102 and alanine (A) at position 300 were both mutated to cysteine (C). The positions of the mutation sites in the model are shown in Figure 1. The sites of mutation (102 and 300) were located on the surface of the enzyme, and were not inside the cavity where the enzyme bound to the substrate.

The recombinant plasmids, pPICZ $\alpha \mathrm{A}-\mathrm{cAlyM}$ and $\mathrm{pPICZ} \alpha \mathrm{A}-102 \mathrm{C} 300 \mathrm{C}$ were successfully constructed and confirmed by DNA sequencing (Ruibiotech, Qingdao, China). These plasmids were transformed into P. pastoris X33 for protein expression. The recombinant yeast colonies, X33-cAlyM and $\mathrm{X} 33-102 \mathrm{C} 300 \mathrm{C}$, fermented as induced by methanol in a shaking flask. The extracellular enzymatic activities of recombinant cAlyM and $102 \mathrm{C} 300 \mathrm{C}$ were $33.82 \mathrm{U} / \mathrm{mL}$ and $33.87 \mathrm{U} / \mathrm{mL}$, respectively. Based on the BLAST search (http://blast.ncbi.nlm.nih.gov/Blast.cgi), we determined that cAlyM and its thermostable mutant $102 \mathrm{C} 300 \mathrm{C}$ belong to the PL-7 family. 


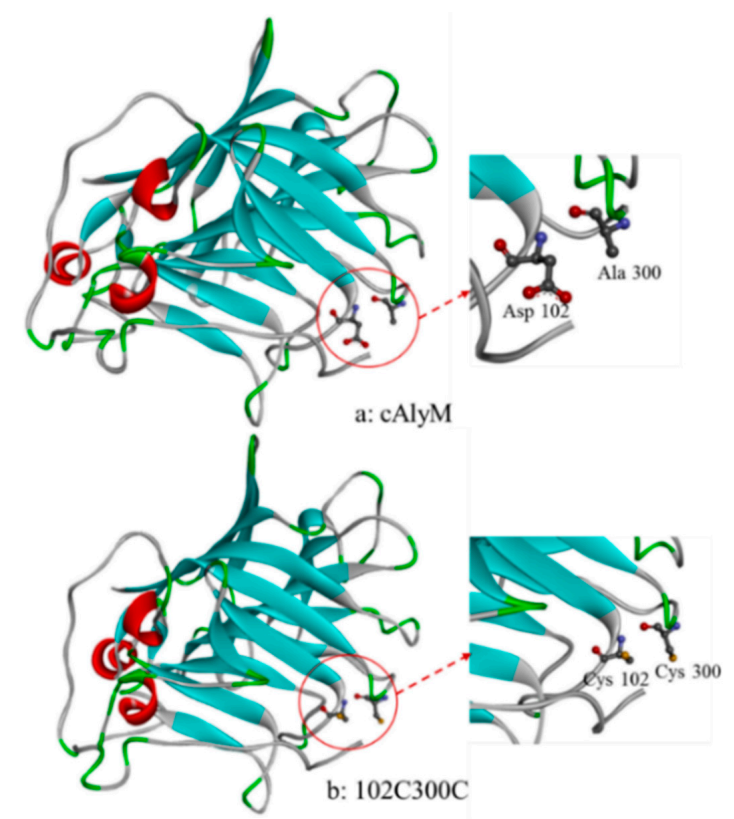

Figure 1. The position of mutation sites in the three-dimensional model of cAlyM (a) and 102C300C (b). The three-dimensional molecular visualization was performed using Phyre2. The arrows point to the magnified structures of the mutation sites.

\subsection{Purification of Recombinant cAlyM and $102 C 300 \mathrm{C}$}

The cAlyM and 102C300C recombinant enzymes were purified using $\mathrm{Ni}^{+}$-chelated magnetic beads. After purification, the specific activities of cAlyM and 102C300C were $277.1 \mathrm{U} / \mathrm{mg}$ and $249.6 \mathrm{U} / \mathrm{mg}$, respectively (Table 1). Due to the different definitions of enzyme activity units, the specific activities of many alginate lyases cannot be directly compared. For alginate lyases with the same definition of enzyme activity unit, the specific activities of cAlyM and 102C300C were higher than that of many reported alginate lyases. As two examples, the specific activity of the recombinant alginate lyase Aly7B_Wf expressed in E. coli from Wenyingzhuangia fucanilytica was $23.24 \mathrm{U} / \mathrm{mg}$ [23] and the specific activity of AlyH1 from Vibrio furnissii $\mathrm{H} 1$ was $2.40 \mathrm{U} / \mathrm{mg}$ [11]. The specific activity of cAylM expressed in E. coli was $1386.27 \mathrm{U} / \mathrm{mg}$ [17], which was higher than that expressed in P. pastoris and it might be caused by the glycosylation modification of enzyme. The predicted glycosylation sites in cAlyM are shown in Figure S1. The glycosylation sites were marked in the gene sequence and observed in the three-dimensional model of cAlyM (Figure S2). Some glycosylation sites were near the highly conserved regions, which might influence the accessibility of the substrate to the enzyme active site through steric hindrance and cause the decrease of the enzyme activity.

Table 1. Purification of cAlyM and 102C300C.

\begin{tabular}{|c|c|c|c|c|c|c|c|}
\hline Enzymes & Step & Total Activity (U) & Total Protein (mg) & $\begin{array}{c}\text { Specific Activity } \\
\text { (U/mg) }\end{array}$ & $\begin{array}{l}\text { Recovery } \\
\text { Rate (\%) }\end{array}$ & Fold & $\begin{array}{c}\text { Yield } \\
\text { (U/mL) }\end{array}$ \\
\hline \multirow{2}{*}{ cAlyM } & Fermentation medium & $507.4 \pm 8.5$ & $3.00 \pm 0.06$ & 169.1 & 100 & 1 & $33.8 \pm 0.57$ \\
\hline & Magnetic beads & $188.4 \pm 4.6$ & $0.68 \pm 0.01$ & 277.1 & 37.13 & 1.64 & $26.9 \pm 0.66$ \\
\hline \multirow{2}{*}{$102 \mathrm{C} 300 \mathrm{C}$} & Fermentation medium & $617.6 \pm 6.4$ & $3.82 \pm 0.05$ & 161.7 & 100 & 1 & $41.2 \pm 0.43$ \\
\hline & Magnetic beads & $237.1 \pm 5.1$ & $0.95 \pm 0.01$ & 249.6 & 38.39 & 1.54 & $33.9 \pm 0.73$ \\
\hline
\end{tabular}

SDS-PAGE resolved two main protein bands with MWs of $43 \mathrm{kDa}$ and $47 \mathrm{kDa}$ in each sample (Figure 2). The calculated MW of cAlyM and 102C300C was $32.9 \mathrm{kDa}$. The difference between the actual value and the theoretical value may be explained by the different glycosylation modifications of the recombinant enzyme. Glycosylation of proteins during synthesis is an important modification that occurs during the secretion of proteins, resulting in the covalent linkage of carbohydrates to asparagine (N-linked) or to serine/threonine (O-linked) residues [24], and N-glycosylation affects 
the folding and transportation of proteins [25]. Various proteins have been cloned and expressed as glycoproteins in P. pastoris. The MW of glycosylated neutral protease reportedly increased from $43.3 \mathrm{kDa}$ to $54.5 \mathrm{kDa}$ [26] and the MW of glycosylated phytase increased from $54 \mathrm{kDa}$ to $75 \mathrm{kDa}$ [27].

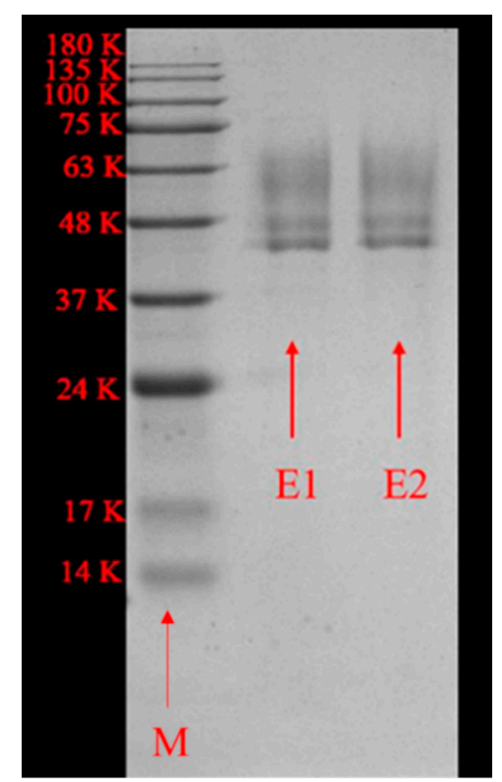

Figure 2. SDS-PAGE of recombinant cAlyM and 102C300C. Lane M, protein marker; lane E1, purified cAlyM; lane E2, purified 102C300C.

\subsection{Kinetic Parameters of cAlyM and 102C300C}

The $K_{m}$ and $V_{\max }$ values were calculated using the Lineweaver-Burk method. As shown in Table 2, cAlyM and 102C300C displayed similar $K_{m}$ values, which was lower than that of some reported alginate lyases [11,28]. For example, three alginate lyases derived from Marinimicrobium sp. H1 were expressed in E. coli, with $K_{m}$ values of $6.6,6.9$, and $7.7 \mathrm{mg} / \mathrm{mL}$ [13]. The $k_{\text {cat }}$ values of cAlyM and 102C300C were similar, which suggested that the mutations at position 102 and 300 did not cause structural changes in the catalytic activity center of the enzyme.

$K_{m}$ value indicated the affinity of enzyme and substrate. The $K_{m}$ values of cAlyM and 102C300C expressed in E. coli were 0.37 and $0.28 \mathrm{mg} / \mathrm{mL}$, respectively [22], which were lower than those expressed in $P$. pastoris. The decrease of affinity of enzyme and substrate was related to the decrease of $V_{\max }$ values, and the $V_{\max }$ values of cAlyM and 102C300C expressed in P. pastoris were both lower than those expressed in E. coli.

Table 2. Enzyme kinetic parameters of cAlyM and 102C300C.

\begin{tabular}{ccccc}
\hline Enzyme & $V_{\text {max }}(\mathrm{U} / \mathbf{m g})$ & $\boldsymbol{K}_{\boldsymbol{m}}(\mathbf{m g} / \mathbf{m L})$ & $\boldsymbol{k}_{\text {cat }}\left(\mathbf{s}^{-\mathbf{1}}\right)$ & $\boldsymbol{k}_{\text {cat }} / \boldsymbol{K}_{\boldsymbol{m}}(\mathrm{mL} / \mathbf{s} / \mathbf{m g})$ \\
\hline cAlyM & $344.8 \pm 5.6$ & $1.31 \pm 0.21$ & $189.1 \pm 5.3$ & 144.3 \\
102C300C & $312.5 \pm 10.1$ & $1.43 \pm 0.20$ & $171.3 \pm 4.3$ & 119.2 \\
\hline
\end{tabular}

\subsection{Enzymatic Properties of cAlyM and 102C300C}

The optimal temperature and $\mathrm{pH}$, effects of metal ions, and substrate specificity of cAlyM and 102C300C were determined and compared. The enzymatic activities reached their optimum at $50{ }^{\circ} \mathrm{C}$ (Figure 3A). Many alginate lyases exhibit optimal enzymatic activity between $30{ }^{\circ} \mathrm{C}$ and $40{ }^{\circ} \mathrm{C}$ [21]. cAlyM and 102C300C displayed maximum activity at pH 8.0 (Figure 3B) and reached more than $80 \%$ activity at $\mathrm{pH} 7.0$ and $\mathrm{pH}$ 9.0. These findings suggested that the enzymes can degrade alginate better under an alkaline condition. The slight changes in the surface charge of 102C300C did not cause the change in optimal $\mathrm{pH}$ of the enzyme. 

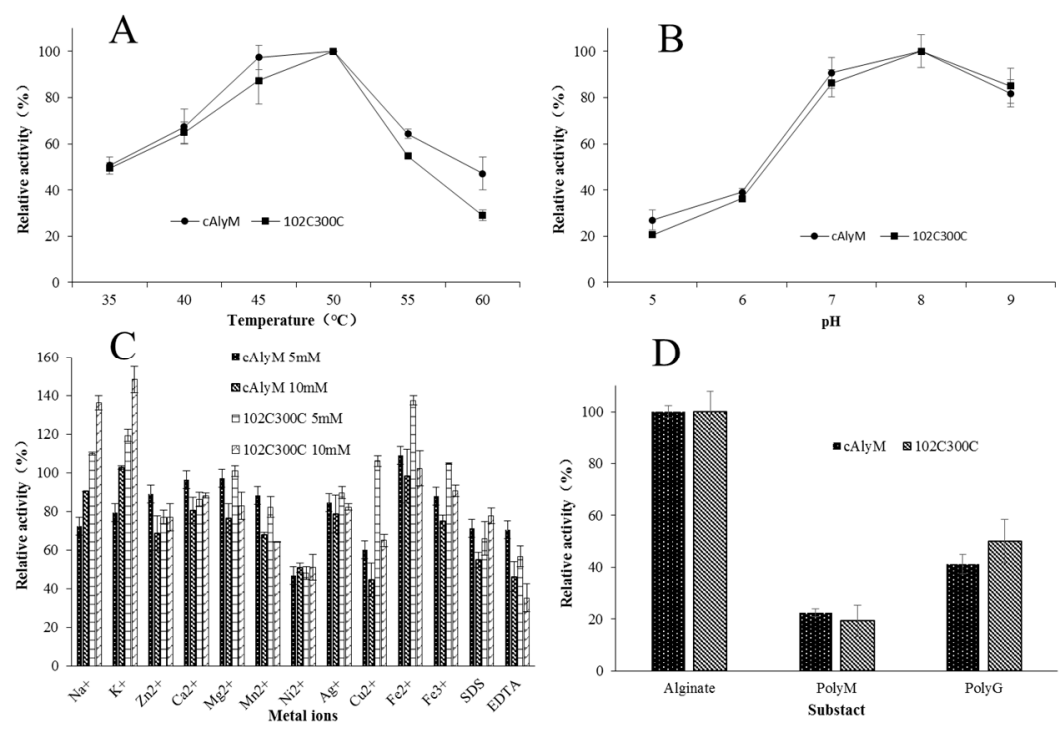

Figure 3. Biochemical properties of cAlyM and 102C300C. (A) The optimal temperatures of cAlyM and 102C300C. (B) Optimal pH of cAlyM and 102C300C. (C) Effect of metal ions on cAlyM and 102C300C. (D) Substrate preference of cAlyM and 102C300C. Values were reported as the mean of three determinations \pm standard deviation.

$\mathrm{Na}^{+}$and $\mathrm{K}^{+}$(both $10 \mathrm{mM}$ ) enhanced 102C300C activity, while $\mathrm{Ni}^{+}$and EDTA had obvious inhibitory effects on the enzymatic activity (Figure 3C). As the concentration of some ions such as $\mathrm{Na}^{+}$ and $\mathrm{K}^{+}$increased, the relative activities of the two enzymes increased. As the concentration of $\mathrm{Mg}^{2+}$, $\mathrm{Mn}^{2+}$, and $\mathrm{Fe}^{3+}$ increased, the relative activities of the two enzymes decreased.

Substrate specificity analysis revealed activities toward sodium alginate, polyG, and polyM (Figure 3D), indicating that the enzymes were a bifunctional alginate lyase. The relative activities towards alginate and polyG were higher than that towards polyM. Some studies have reported that the substrate specificity of alginate lyase is related to the conserved amino acids in the gene [29]. The mutation sites of $102 \mathrm{C} 300 \mathrm{C}$ were located on the surface of the protein and were not conserved amino acids, and so did not cause a significant change in substrate specificity.

\subsection{Thermal Stability of cAlyM and 102C300C}

Mutant 102C300C was designed for the thermal stability of cAlyM, so the difference in thermostability between the two enzymes was important to determine, to judge whether the mutation was favorable. After incubation at $45^{\circ} \mathrm{C}, 50{ }^{\circ} \mathrm{C}, 55^{\circ} \mathrm{C}$, and $60^{\circ} \mathrm{C}$ for $5 \mathrm{~min}$, the difference in relative activity was evident at temperatures of $50^{\circ} \mathrm{C}$ and above. The remaining enzymatic activities of $102 \mathrm{C} 300 \mathrm{C}$ at $55^{\circ} \mathrm{C}$ and $60^{\circ} \mathrm{C}$ were higher than those of cAlyM (Figure $4 \mathrm{~A}$ ). After treatment at $55^{\circ} \mathrm{C}$ for $5 \mathrm{~min}$, the relative activities of cAlyM and 102C300C were $44 \%$ and $52 \%$ of the original activity, respectively. The half-life values at $45{ }^{\circ} \mathrm{C}\left(\mathrm{t}_{1 / 2,45^{\circ} \mathrm{C}}\right)$ of cAlyM and $102 \mathrm{C} 300 \mathrm{C}$ were $2.0 \mathrm{~h}$ and $5.2 \mathrm{~h}$,

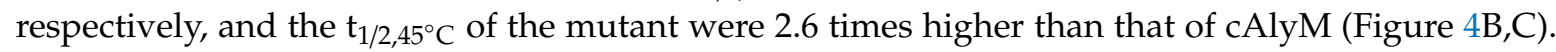
The half-life values at $50{ }^{\circ} \mathrm{C}\left(\mathrm{t}_{1 / 2,50^{\circ} \mathrm{C}}\right)$ of cAlyM and $102 \mathrm{C} 300 \mathrm{C}$ were $0.3 \mathrm{~h}$ and $3.5 \mathrm{~h}$, respectively, and

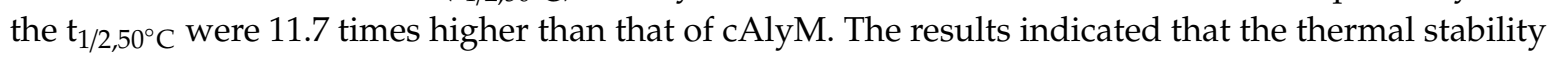
of 102C300C had improved. The data indicated that the strategy of adding disulfide bonds within the protein to improve protein thermal stability is feasible in the rational design of enzymes.

Compared with many reported alginate lyases, 102C300C exhibited good thermostability (Table 3). For example, the recombinant alginate lyase algA expressed in E. coli from Pseudomonas sp. E03 lost $50 \%$ activity at $50{ }^{\circ} \mathrm{C}$ for $30 \mathrm{~min}$ [28]. KJ-2 expressed in E. coli from Stenotrophomas maltophilia was inactivated at temperatures exceeding $40^{\circ} \mathrm{C}$ for $30 \mathrm{~min}$ [30]. The relatively higher specific activity and good thermostability of $102 \mathrm{C} 300 \mathrm{C}$ favor its use in the production of AOS. Among the reported alginate lyases, some alginate lyases showed a good thermostability. SAGL expressed in P. pastoris 
from Flavobacterium sp. $\mathrm{H} 63$ retained $49.0 \%$ activity at $50{ }^{\circ} \mathrm{C}$ for $72 \mathrm{~h}$, which had polyM preference [20]. AlgC-PL7 expressed in E. coli from Cobetia sp. NAP1 retained $80 \%$ activity at $70{ }^{\circ} \mathrm{C}$ for $1 \mathrm{~h} \mathrm{[31].}$ GLyase from Pseudomonas sp. F6 retained $60 \%$ activity at $80^{\circ} \mathrm{C}$ for $15 \mathrm{~min}$ [32].
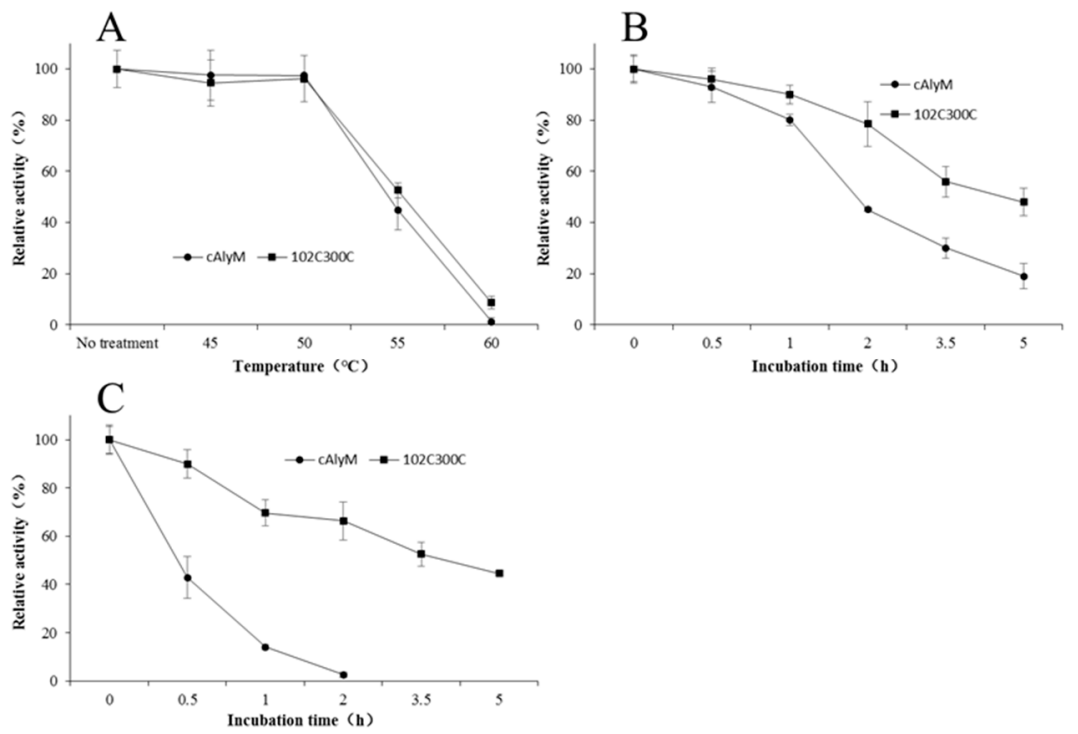

Figure 4. Thermal stability properties of cAlyM and 102C300C (A) Residual activities of cAlyM and 102C300C after incubation at different temperatures for $5 \mathrm{~min}$. Residual activities of cAlyM and $102 \mathrm{C} 300 \mathrm{C}$ after incubation at $45^{\circ} \mathrm{C}(\mathrm{B})$ and $50{ }^{\circ} \mathrm{C}(\mathrm{C})$ for different times. Values were reported as the mean of three determinations \pm standard deviation.

Table 3. Data of some reported alginate lyases.

\begin{tabular}{|c|c|c|c|c|c|c|c|}
\hline Enzyme & Origin & Source & $\begin{array}{l}\text { Substrate } \\
\text { Preference }\end{array}$ & $\begin{array}{c}\text { Optimal Catalytic } \\
\text { Temperature }\end{array}$ & Thermalstability & $\begin{array}{c}\text { Specific activity } \\
\text { (U/mg) }\end{array}$ & Reference \\
\hline Aly08 & Vibrio sp. SY01 & E. coli & Poly G & $45^{\circ} \mathrm{C}$ & $\begin{array}{c}\text { Retained } 48.7 \% \text { activity at } \\
20^{\circ} \mathrm{C} \text { for } 1 \mathrm{~h}\end{array}$ & 841 & [14] \\
\hline Aly7B_Wf & $\begin{array}{l}\text { Wenyingzhuangia } \\
\text { fucanilytica }\end{array}$ & E. coli & Poly M & $40{ }^{\circ} \mathrm{C}$ & $\begin{array}{c}\text { Retained } 75 \% \text { activity at } 35 \\
{ }^{\circ} \mathrm{C} \text { for } 24 \mathrm{~h}\end{array}$ & $23.24 *$ & [23] \\
\hline AlyH1 & $\begin{array}{l}\text { Vibrio furnissii } \\
\text { H1 }\end{array}$ & Native & Poly G & $40^{\circ} \mathrm{C}$ & $\begin{array}{l}\text { Retained } 60 \% \text { activity at } 40 \\
{ }^{\circ} \mathrm{C} \text { for } 30 \mathrm{~min}\end{array}$ & $2.40 *$ & [11] \\
\hline FsAlgB & $\begin{array}{l}\text { Flammeovirga sp. } \\
\text { NJ-04 }\end{array}$ & E. coli & Poly $\mathrm{M}$ and alginate & $40^{\circ} \mathrm{C}$ & $\begin{array}{l}\text { Retained } 80 \% \text { activity at } 40 \\
{ }^{\circ} \mathrm{C} \text { for } 30 \mathrm{~min}\end{array}$ & 1760.8 & [15] \\
\hline $\mathrm{AlgH}$ & $\begin{array}{l}\text { Marinimicrobium } \\
\text { sp. H1 }\end{array}$ & E. coli & Poly G & $45^{\circ} \mathrm{C}$ & $\begin{array}{l}\text { Retained } 80 \% \text { activity at } 40 \\
{ }^{\circ} \mathrm{C} \text { for } 2 \mathrm{~h}\end{array}$ & 5510 & [13] \\
\hline PmC5A & $\begin{array}{l}\text { Pseudomonas } \\
\text { mendocina } \\
\text { DICP-70 }\end{array}$ & E. coli & Poly G and Poly M & $40^{\circ} \mathrm{C}$ & $\begin{array}{c}\text { Retained } 80 \% \text { activity at } 45 \\
{ }^{\circ} \mathrm{C} \text { for } 1 \mathrm{~h}\end{array}$ & N.D. & [16] \\
\hline Aly1281 & $\begin{array}{c}\text { Pseudoalteromonas } \\
\text { carrageenovora } \\
\text { ASY5 }\end{array}$ & E. coli & Poly G & $50^{\circ} \mathrm{C}$ & $\begin{array}{l}\text { Stable at temperatures } \\
\text { lower than } 55^{\circ} \mathrm{C}\end{array}$ & $1.15^{*}$ & [33] \\
\hline Alg17B & BP-2 & Native & Poly M & $45^{\circ} \mathrm{C}$ & $\begin{array}{c}\text { Retained } 10 \% \text { activity at } 45 \\
{ }^{\circ} \mathrm{C} \text { for } 1 \mathrm{~h}\end{array}$ & 4036 & [12] \\
\hline $\mathrm{KJ}-2$ & $\begin{array}{l}\text { Stenotrophomas } \\
\text { maltophilia } \mathrm{KJ}-2\end{array}$ & E. coli & Poly MG & $40^{\circ} \mathrm{C}$ & $\begin{array}{l}\text { Inactivated at higher than } \\
40^{\circ} \mathrm{C} \text { for } 30 \mathrm{~min}\end{array}$ & 848.3 & [30] \\
\hline $\operatorname{alg} \mathrm{A}$ & $\begin{array}{l}\text { Pseudomonas sp. } \\
\text { E03 }\end{array}$ & E. coli & Poly M & $30^{\circ} \mathrm{C}$ & $\begin{array}{c}\text { Retained } 50 \% \text { activity at } 50 \\
{ }^{\circ} \mathrm{C} \text { for } 30 \mathrm{~min}\end{array}$ & 222 & [28] \\
\hline SAGL & $\begin{array}{l}\text { Flavobacterium } \\
\text { sp. H63 }\end{array}$ & P. pastoris & Poly $\mathrm{M}$ and alginate & $45^{\circ} \mathrm{C}$ & $\begin{array}{c}\text { Retained } 49.0 \% \text { activity at } \\
50^{\circ} \mathrm{C} \text { for } 72 \mathrm{~h}\end{array}$ & $4044^{*}$ & [20] \\
\hline AlgC-PL7 & $\begin{array}{l}\text { Cobetia sp. } \\
\text { NAP1 }\end{array}$ & E. coli & Poly G and Poly M & $45^{\circ} \mathrm{C}$ & $\begin{array}{c}\text { Retained } 80 \% \text { activity at } 70 \\
{ }^{\circ} \mathrm{C} \text { for } 1 \mathrm{~h}\end{array}$ & 30 & [31] \\
\hline GLyase & $\begin{array}{l}\text { Pseudomonas sp. } \\
\text { F6 }\end{array}$ & Native & Poly G & N.D. & $\begin{array}{l}\text { Retained } 60 \% \text { activity at } 80 \\
{ }^{\circ} \mathrm{C} \text { for } 15 \mathrm{~min}\end{array}$ & 222.8 & [32] \\
\hline cAlyM & $\begin{array}{c}\text { Microbulbifer sp. } \\
\text { Q7 }\end{array}$ & P. pastoris & Poly G and alginate & $50{ }^{\circ} \mathrm{C}$ & $\begin{array}{c}\text { Retained } 50 \% \text { activity at } 45 \\
{ }^{\circ} \mathrm{C} \text { for } 2 \mathrm{~h}\end{array}$ & $277.1 *$ & This study \\
\hline $102 \mathrm{C} 300 \mathrm{C}$ & $\begin{array}{c}\text { Microbulbifer sp. } \\
\text { Q7 }\end{array}$ & P. pastoris & Poly $\mathrm{G}$ and alginate & $50^{\circ} \mathrm{C}$ & $\begin{array}{c}\text { Retained } 50 \% \text { activity at } 45 \\
{ }^{\circ} \mathrm{C} \text { for } 5.2 \mathrm{~h}\end{array}$ & $249.6^{*}$ & This study \\
\hline
\end{tabular}

Note: "** indicates that alginate lyase activity is measured using the DNS method. Alginate lyase activity not denoted with "*" was measured by the $235 \mathrm{~nm}$ absorbance method and one unit of activity was defined as the amount of enzyme required to increase the absorbance at $235 \mathrm{~nm}$ by 0.1 per min.

\subsection{ESI-MS and HPLC Analyses of Degradation Products}

The degradation products of $102 \mathrm{C} 300 \mathrm{C}$ were identified by ESI-MS. Ions at 351,571 , and $769 \mathrm{~m} / \mathrm{z}$ represented unsaturated disaccharides $(352 \mathrm{Da})$, unsaturated trisaccharides $(572 \mathrm{Da})$, and unsaturated 
tetrasaccharides (770 Da), respectively (Figure 5). It proved that oligosaccharides with a polymerization degree of 2-4 were the final hydrolytic products. Compared with the analysis of the degradation products of cAlyM [34], the ESI-MS result of 102C300C was consistent with that of cAlyM, indicating that the mutant did not change the action model of alginate lyase.

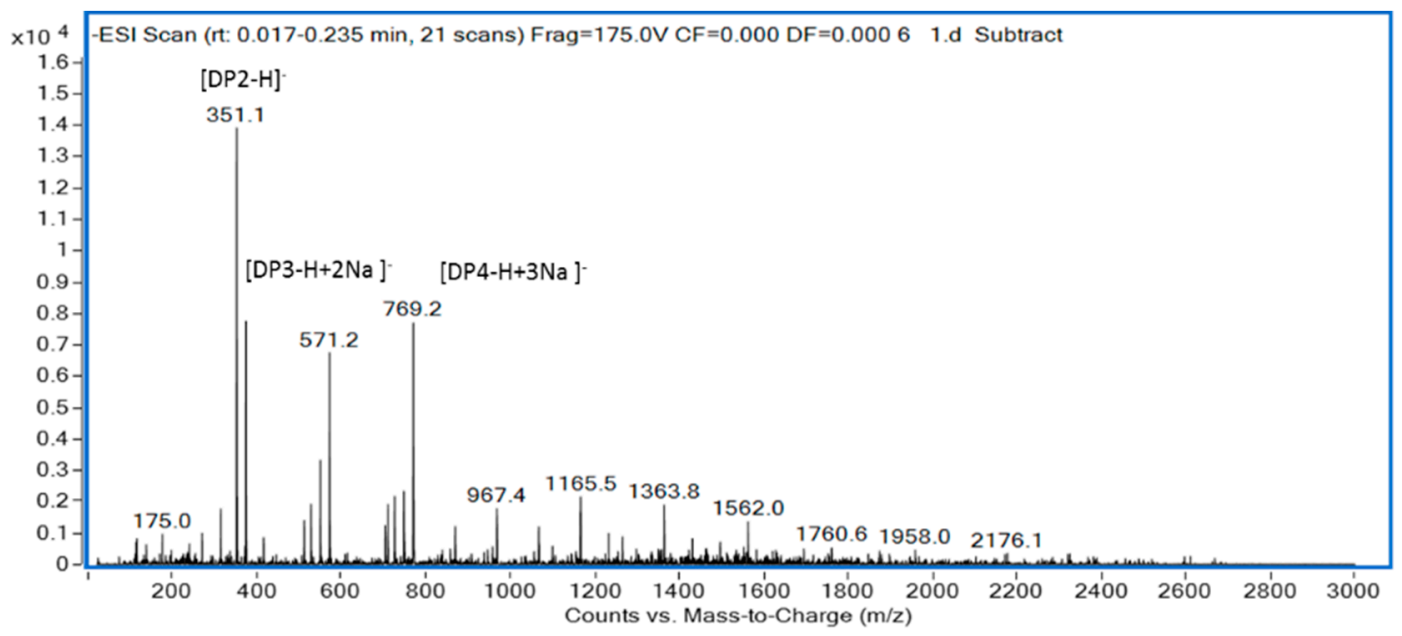

Figure 5. ESI-MS of the102C $300 \mathrm{C}$ degradation products.

HPLC analysis revealed that the degradation products precipitated by 1-, 3-, and 5-fold ethanol had MWs of $4.92 \mathrm{kDa}, 3.49 \mathrm{kDa}$, and $2.31 \mathrm{kDa}$, respectively (data not shown). The yields of the degradation products precipitated by 1-, 3-, and 5-fold ethanol were $11.67 \%, 83.55 \%$ and $2.20 \%$, respectively, and the yield of unhydrolyzed part was $0.98 \%$. As shown in Table 4 , the $\mathrm{M} / \mathrm{G}$ ratios of the degradation products precipitated by 1-, 3-, and 5-fold ethanol were 2.44, 0.85, and 0.37, respectively. As the MW of the degradation product decreased, the proportion of $\mathrm{G}$ in the monosaccharide composition gradually increased, indicating a preferential polyG substrate specificity of 102C300C, which was consistent with the result of substrate specificity. Many reports have described immunoregulatory, antimicrobial, and anti-inflammatory activities of $\alpha$-L-guluronic acid oligosaccharides (GOS), the degradation product of alginate. For example, GOS displays anti-inflammatory activity on lipopolysaccharide-activated murine macrophages [35]. GOS can strengthen the action of antibiotics and destroy bacterial biofilms by binding to the bacterial surfaces, regulating surface charges, inducing microbial aggregation, and inhibiting motility [36].

Table 4. M/G ratios and yield of degradation products precipitated using different volumes of ethanol.

\begin{tabular}{cccc}
\hline Sample & Peak Area Percentage of G & Peak Area Percentage of M & M/G \\
\hline 1-fold & $15.05 \%$ & $84.95 \%$ & 5.61 \\
3-fold & $31.17 \%$ & $68.83 \%$ & 2.08 \\
5-fold & $72.91 \%$ & $27.09 \%$ & 0.37 \\
\hline
\end{tabular}

\section{Materials and Methods}

\subsection{Strains, Plasmids, and Reagents}

The alginate lyase gene cAlyM from Microbulbifer sp. Q7 (CGMCC 14061) was optimized according to $P$. pastoris codon usage bias. The codon-optimized gene synthesized by Shanghai TY Biotechnology Co. Ltd. (Shanghai, China) was inserted into the plasmid pPIC9K. The recombinant plasmid was named as pPIC9K-cAlyM. E. coli DH5 $\alpha$, P. pastoris strain X33, and plasmid pPICZ $\alpha$ were conserved in our laboratory. E. coli DH5 $\alpha$ was used for plasmid construction. P. pastoris X33 was used for eukaryotic expression. Sodium alginate (M/G ratio 0.85 ), polyM, and polyG blocks (purity $>90 \%$ ) were purchased from Qingdao BZLH Biotech Co. Ltd. (Qingdao, China). The antibiotic zeocin was 
purchased from Beijing Solaribio Technology Co. Ltd. (Beijing, China). Restriction enzymes EcoRI, NotI, and SacI were purchased from Thermo Fisher Scientific (Waltham, MA, USA).

\subsection{Construction of Alginate Lyase and Mutant Recombinant Plasmid}

The codon-optimized alginate lyase gene was amplified from pPIC9K-cAlyM by PCR using $5^{\prime}$-AGAGAGGCTGAAGCTGAATTCACTGAATCTGGTTCTGGTTCTTCTT-3' as the upstream primer and $5^{\prime}$-TGTTCTAGAAAGCTGGCGGCCGCTTAGTGGTGATGGTGATGATGATC-3' as the downstream primer. Plasmid pPICZ $\alpha$ was digested with EcoRI and NotI. The purified cAlyM fragment was ligated into plasmid $\mathrm{pPICZ} \alpha$ at the EcoRI and NotI sites. The recombinant plasmid was named as pPICZ $\alpha$-cAlyM.

Site-directed mutagenesis was used to construct the mutant recombinant plasmid. The recombinant plasmid pPICZ $\alpha$-cAlyM was used as the template to amplify the mutation plasmids by PCR using the following primers: D102C-F: ATGTCCAATCTGTGGTTACAAGACTTCTACCAACACCTCC; D102C-R, TCTTGTAACCACAGATTGGACATCTGAACACCATACCAC, A300C-F: TACTGGTAACTGTTCCGACTACGTTCAGGTTACTTTCTAC, and A300C-R: CGTAGTCGGAACAGTTACCAGTATTGTTCTGGTTGTAAACAC. DpnI was used to remove the template DNA from the PCR product. The linearized PCR product was purified and ligated. The mutant recombinant plasmid was named as pPICZ $\alpha-102 \mathrm{C} 300 \mathrm{C}$.

\subsection{Transformation and Colony Screening of P. pastoris}

Recombinant plasmids pPICZ $\alpha$-cAlyM and pPICZ $\alpha-102 C 300 C$ were digested with SacI. The linearized form of the recombinant plasmids were transformed into P. pastoris X33 competent cells by electroporation at $2.0 \mathrm{kV}$ using a one-pulse electroporation cuvette, and selected on YPDS plates containing $100 \mu \mathrm{g} / \mathrm{mL}$ zeocin. After $72 \mathrm{~h}, 24$ yeast colonies were picked from each plate and cultivated in $1 \mathrm{~mL}$ BMGY by inoculating into a 48-pore plate at $30^{\circ} \mathrm{C}$ and $200 \mathrm{rpm}$ for $72 \mathrm{~h}$. Methanol was added to a final concentration of $1 \%$ every $24 \mathrm{~h}$ to induce the expression of alginate lyase. After the enzymatic activity assay, some positive recombinant yeast colonies were inoculated in $20 \mathrm{~mL}$ YPD medium at $30{ }^{\circ} \mathrm{C}$ and $200 \mathrm{rpm}$ for $24 \mathrm{~h}$. The cells were collected by centrifugation $10,000 \mathrm{rpm}$ at $4{ }^{\circ} \mathrm{C}$ for $10 \mathrm{~min}$, resuspended in $20 \mathrm{~mL}$ BMGY medium, and incubated at $30^{\circ} \mathrm{C}$ and $200 \mathrm{rpm}$ for $72 \mathrm{~h}$ with methanol added to a final concentration of $1 \%$ every $24 \mathrm{~h}$. Positive recombinant yeast colonies were named as X33-cAlyM and X33-102C300C, respectively.

\subsection{Purification of Recombinant cAlyM and 102C300C}

The recombinant enzymes cAlyM and 102C300C fused with a His6 tag were purified using $\mathrm{Ni}^{+}$-chelated magnetic beads (Suzhou Beaver Biomedical Co. Ltd., Suzhou, China). The manufacturer's purification protocol was followed. The concentrations of imidazole in the binding buffer and elution buffer were $50 \mathrm{mM}$ and $100 \mathrm{mM}$, respectively. The purified enzymes were further analyzed by $12 \%$ SDS-PAGE. The protein concentration was determined by the Coomassie Brilliant Blue method and measured by absorbance at $295 \mathrm{~nm}$ [37]. The purified recombinant enzymes were named as cAlyM and $102 \mathrm{C} 300 \mathrm{C}$.

\subsection{Enzymatic Activity Assay}

Enzyme activity was determined by the 3,5-dinitrosalicylic acid (DNS) method [38]. Nine hundred microliters of sodium alginate $(0.8 \%, \mathrm{pH} 7.0)$ was mixed with $100 \mu \mathrm{L}$ of the recombinant enzyme and reacted at $45^{\circ} \mathrm{C}$ for $5 \mathrm{~min}$. The reaction was terminated by adding $1 \mathrm{~mL}$ of DNS solution. The mixture was incubated in a boiling water bath for $5 \mathrm{~min}$ and $\mathrm{ddH}_{2} \mathrm{O}$ was added to a total volume of $10 \mathrm{~mL}$. Absorbance was measured at $540 \mathrm{~nm}$. One unit of the enzyme (U) was defined as the amount of enzyme causing the release of $1 \mu \mathrm{mol}$ of reducing sugar from alginate per minute. 


\subsection{Kinetic parameters of cAlyM and $102 C 300 C$}

The kinetic parameters of the enzymes were determined by measuring the enzyme activities of the purified enzymes at different concentrations $(0.5-8 \mathrm{mg} / \mathrm{mL})$ of sodium alginate. The $K_{m}$ and $V_{\max }$ values were calculated using the Lineweaver-Burk method.

\subsection{Enzymatic Properties of cAlyM and 102C300C}

The optimal catalytic temperatures of cAlyM and 102C $300 \mathrm{C}$ were determined by measuring activity from $35^{\circ} \mathrm{C}$ to $60^{\circ} \mathrm{C}$ in $100 \mathrm{mM}$ phosphate buffer ( $\mathrm{pH}$ 7.0). The optimal catalytic $\mathrm{pH}$ value was determined by measuring activity at various $\mathrm{pH}$ values ranging from 5.0 to 9.0 in $100 \mathrm{mM}$ phosphate buffer. Substrate specificity was determined by measuring activity upon reaction with $2 \mathrm{mg} / \mathrm{mL}$ of sodium alginate, polyM, and polyG. The highest enzyme activity was taken as $100 \%$.

To determine the influence of metal ions on the activity of cAlyM and $102 \mathrm{C} 300 \mathrm{C}$, the recombinant enzymes were incubated with various metal ions at a final concentration of $5 \mathrm{mM}$ and $10 \mathrm{mM}$ at $4{ }^{\circ} \mathrm{C}$ for $2 \mathrm{~h}$. Activity was measured and the reaction mixture without any metal ions was taken as $100 \%$. The metal ions included $\mathrm{Na}^{+}, \mathrm{K}^{+}, \mathrm{Zn}^{2+}, \mathrm{Ca}^{2+}, \mathrm{Mg}^{2+}, \mathrm{Mn}^{2+}, \mathrm{Ni}^{2+}, \mathrm{Ag}^{+}, \mathrm{Cu}^{2+}, \mathrm{Fe}^{2+}, \mathrm{Fe}^{3+}$ and SDS.

\subsection{Thermal Stability of cAlyM and 102C300C}

The recombinant enzymes were incubated at various temperatures ranging from $45^{\circ} \mathrm{C}$ to $60^{\circ} \mathrm{C}$ for $5 \mathrm{~min}$, and the residual enzyme activity of the sample was measured. To determine the half-life value, the residual activity was measured after incubating at $45^{\circ} \mathrm{C}$ and $50{ }^{\circ} \mathrm{C}$ for different times. The reaction mixture without any heat treatment was taken as $100 \%$.

\subsection{ESI-MS and HPLC Analyses of Degradation Products}

The sample prepared through the hydrolysis of $102 \mathrm{C} 300 \mathrm{C}$ on alginate was analyzed by ESI-MS and HPLC. In this hydrolysis reaction, $2 \%$ sodium alginate was degraded at $45^{\circ} \mathrm{C}$ for $8 \mathrm{~h}$ by adding $1 \%$ $102 \mathrm{C} 300 \mathrm{C}$ every $2 \mathrm{~h}$. The degradation products were vacuum freeze-dried and analyzed by negative ion ESI-MS (Agilent 1290 Infinity II-6460, Frag = 175.0 V, m/z 100-2000 amu).

To determine the molecular weight (MW) of the degradation products, the degradation products were prepared by gradient ethanol precipitation. The precipitates were freeze-dried and analyzed by HPLC (Agilent 1260 Infinity HPLC system) using a PL Aquagel-OH 30 column (Agilent, Santa Clara, CA, USA). $\mathrm{NaNO}_{3}(200 \mathrm{mM})$ with $10 \mathrm{mM} \mathrm{NaH}_{2} \mathrm{PO}_{4}$ was used as the mobile phase at a flow rate of $0.5 \mathrm{~mL} / \mathrm{min}$. The column temperature was $25^{\circ} \mathrm{C}$ and a refractive index detector (RID) was used. Dextrans (MWs: 1, 3.65, 5 and $12 \mathrm{kDa}$ ) were used as standards. Before injection, the precipitates were dissolved in the mobile phase and passed through a $0.22 \mu \mathrm{m}$ filter. To determine the monosaccharide composition of the degradation products, the precipitates were decomposed by $2 \mathrm{M}$ trifluoroacetic acid (TFA) at $110^{\circ} \mathrm{C}$ for $4 \mathrm{~h}$ and detected by HPLC using an XDB-C18 column (Agilent) after pre-column derivatization using 1-phenyl-3-methyl-5-pyrazolone (PMP). $\mathrm{KH}_{2} \mathrm{PO}_{4}(50 \mathrm{mM}, \mathrm{pH}$ 6.9) was used as the mobile phase at a flow rate of $1 \mathrm{~mL} / \mathrm{min}$. The column temperature was $25^{\circ} \mathrm{C}$ and detection was done using an ultraviolet detector at $245 \mathrm{~nm}$. The standards were mannuronate monosaccharide and guluronate monosaccharide.

\section{Conclusions}

With codon optimization of the alginate lyase gene, the recombinant alginate lyase cAlyM and its thermostable mutant 102C $300 \mathrm{C}$ were expressed and characterized in P. pastoris. 102C $300 \mathrm{C}$ displayed higher activity and thermal stability than previously reported alginate lyases. The specific activity

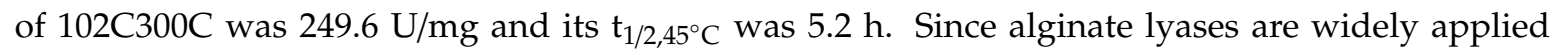
for the preparation of functional oligosaccharides, seaweed fertilizers and feed additives, which areusually performed under high temperature. This work provides a valuable reformation method for thermostable alginate lyases to meet the requirement of industrial application. 
Supplementary Materials: The following are available online at http://www.mdpi.com/1660-3397/18/6/305/s1. Figure S1: The prediction results of O-glycosylation (A) and N-glycosylation (B) of cAlyM. Figure S2: The predicted glycosylation sites in the gene sequence of cAlyM (A). The predicted N-glycosylation sites in the three-dimensional model of cAlyM (B).

Author Contributions: S.Y. and M.Y. conceived and designed the experiments; S.Y., Z.L. and X.F. performed the experiments; C.Z. and Q.K. analyzed the data; S.Y. wrote the paper; H.M. and M.Y. revised the paper. All authors have read and agreed to the published version of the manuscript.

Funding: This research was funded by Shandong Province Key Research and Development Project (2017YYSP003) and Natural Science Foundation of Shandong Province (ZR2017MD006).

Conflicts of Interest: The authors declare no conflict of interest.

\section{References}

1. Zhu, B.; Yin, H. Alginate lyase: Review of major sources and classification, properties, structure-function analysis and applications. Bioengineered 2015, 6, 125-131. [CrossRef] [PubMed]

2. Smidsrod, O.; Haug, A.; Larsen, B.R. The influence of $\mathrm{pH}$ on the rate of hydrolysis of acidic polysaccharides. Acta Chem. Scand. 1966, 20, 1026-1034. [CrossRef] [PubMed]

3. Reddy, B.H.N.; Rauta, P.R.; Lakshmi, V.V.; Sreenivasa, S. Development, formulation, and evaluation of sodium alginate-g-poly (acryl amide-co-acrylic acid/cloiste-30b)/agnps hydrogel composites and their applications in paclitaxel drug delivery and anticancer activity. Int. J. Appl. Pharm. 2018, 10, 141-150.

4. Draget, K.I.; Skjåk-Bræk, G.; Stokke, B.T. Similarities and differences between alginic acid gels and ionically crosslinked alginate gels. Food Hydrocoll. 2006, 20, 170-175. [CrossRef]

5. Xing, M.; Cao, Q.; Wang, Y.; Xiao, H.; Zhao, J.; Zhang, Q.; Ji, A.; Song, S. Advances in research on the bioactivity of alginate oligosaccharides. Mar. Drugs 2020, 18, 144. [CrossRef]

6. Wilcox, M.D.; Brownlee, I.A.; Richardson, J.C.; Dettmar, P.W.; Pearson, J.P. The modulation of pancreatic lipase activity by alginates. Food Chem. 2014, 146, 479-484. [CrossRef]

7. Fang, W.; Bi, D.; Zheng, R.; Cai, N.; Xu, H.; Zhou, R.; Lu, J.; Wan, M.; Xu, X. Identification and activation of TLR4-mediated signalling pathways by alginate-derived guluronate oligosaccharide in RAW264. 7 macrophages. Sci. Rep. 2017, 7, 1-13.

8. Han, Y.; Zhang, L.; Yu, X.; Wang, S.; Xu, C.; Yin, H.; Wang, S. Alginate oligosaccharide attenuates $\alpha 2$, 6-sialylation modification to inhibit prostate cancer cell growth via the Hippo/YAP pathway. Cell Death Dis. 2019, 10, 1-14. [CrossRef]

9. Xin, M.; Ren, L.; Sun, Y.; Li, H.H.; Guan, H.S.; He, X.X.; Li, C.X. Anticoagulant and antithrombotic activities of low-molecular-weight propylene glycol alginate sodium sulfate (PSS). Eur. J. Med. Chem. 2016, 114, $33-40$. [CrossRef]

10. Wang, X.; Sun, G.; Feng, T.; Zhang, J.; Huang, X.; Wang, T.; Xie, Z.; Chu, X.; Yang, J.; Wang, H. Sodium oligomannate therapeutically remodels gut microbiota and suppresses gut bacterial amino acids-shaped neuroinflammation to inhibit Alzheimer's disease progression. Cell Res. 2019, 29, 787-803. [CrossRef]

11. Zhu, X.; Li, X.; Shi, H.; Zhou, J.; Tan, Z.; Yuan, M.; Yao, P.; Liu, X. Characterization of a novel alginate lyase from marine bacterium Vibrio furnissii H1. Mar. Drugs 2018, 16, 30. [CrossRef] [PubMed]

12. Huang, G.; Wen, S.; Liao, S.; Wang, Q.; Huang, S. Characterization of a bifunctional alginate lyase as a new member of the polysaccharide lyase family 17 from a marine strain BP-2. Biotechnol. Lett. 2019, 41, 1187-1200. [CrossRef] [PubMed]

13. Yan, J.; Chen, P.; Zeng, Y.; Men, Y.; Mu, S.; Zhu, Y.; Chen, Y.; Sun, Y. The characterization and modification of a novel bifunctional and robust alginate lyase derived from Marinimicrobium sp. H1. Mar. Drugs 2019, 17, 545. [CrossRef] [PubMed]

14. Wang, Y.; Chen, X.; Bi, X.; Ren, Y.; Han, Q.; Zhou, Y.; Han, Y.; Yao, R.; Li, S. Characterization of an alkaline alginate lyase with $\mathrm{pH}$-stable and thermo-tolerance property. Mar. Drugs 2019, 17, 308. [CrossRef] [PubMed]

15. Zhu, B.; Ni, F.; Sun, Y.; Ning, L.; Yao, Z. Elucidation of degrading pattern and substrate recognition of a novel bifunctional alginate lyase from Flammeovirga sp. NJ-04 and its use for preparation alginate oligosaccharides. Biotechnol. Biofuels 2019, 12, 1-13. [CrossRef]

16. Sun, M.; Sun, C.; Li, T.; Li, K.; Yan, S.; Yin, H. Characterization of a novel bifunctional mannuronan C-5 epimerase and alginate lyase from Pseudomonas mendocina sp. DICP-70. Int. J. Biol. Macromol. 2020, 150, 662-670. [CrossRef] 
17. Yang, M.; Li, N.; Yang, S.; Yu, Y.; Han, Z.; Li, L.; Mou, H. Study on expression and action mode of recombinant alginate lyases based on conserved domains reconstruction. Appl. Microbiol. Biotechnol. 2019, 103, 807-817. [CrossRef]

18. Spohner, S.C.; Müller, H.; Quitmann, H.; Czermak, P. Expression of enzymes for the usage in food and feed industry with Pichia pastoris. J. Biotechnol. 2015, 202, 118-134. [CrossRef]

19. Zhu, T.; Sun, H.; Wang, M.; Li, Y. Pichia pastoris as a versatile cell factory for the production of industrial enzymes and chemicals: Current status and future perspectives. Biotechnol. J. 2019, 14, 1800694. [CrossRef]

20. Li, H.; Wang, S.; Zhang, Y.; Chen, L. High-level expression of a thermally stable alginate lyase using pichia pastoris, characterization and application in producing brown alginate oligosaccharide. Mar. Drugs 2018, 16, 158. [CrossRef]

21. Kim, H.S.; Lee, C.-G.; Lee, E.Y. Alginate lyase: Structure, property, and application. Biotechnol. Bioprocess Eng. 2011, 16, 843-851. [CrossRef]

22. Yang, M.; Yang, S.-X.; Liu, Z.-M.; Li, N.-N.; Li, L.; Mou, H.-J. Rational design of alginate lyase from Microbulbifer sp. Q7 to improve thermal stability. Mar. Drugs 2019, 17, 378. [CrossRef] [PubMed]

23. Pei, X.; Chang, Y.; Shen, J. Cloning, expression and characterization of an endo-acting bifunctional alginate lyase of marine bacterium Wenyingzhuangia fucanilytica. Protein Expr. Purif. 2019, 154, 44-51. [CrossRef] [PubMed]

24. Adney, W.S.; Jeoh, T.; Beckham, G.T.; Chou, Y.-C.; Baker, J.O.; Michener, W.; Brunecky, R.; Himmel, M.E. Probing the role of N-linked glycans in the stability and activity of fungal cellobiohydrolases by mutational analysis. Cellulose 2009, 16, 699-709. [CrossRef]

25. Skropeta, D. The effect of individual N-glycans on enzyme activity. Bioorg. Med. Chem. 2009, 17, $2645-2653$. [CrossRef] [PubMed]

26. Da, L.; Yang, X.; He, Q.; Pan, Y.; Li, Y. Glycosylation analysis of recombinant neutral protease I from Aspergillus oryzae expressed in Pichia pastoris. Biotechnol. Lett. 2013, 35, 2121-2127.

27. Polizeli, M.d.L.T.d.M. Biochemical properties of glycosylation and characterization of a histidine acid phosphatase (phytase) expressed in Pichia pastoris. Protein Expr. Purif. 2014, 99, 43-49.

28. Zhu, B.W.; Huang, L.-S.-X.; Tan, H.-D.; Qin, Y.-Q.; Du, Y.-G.; Yin, H. Characterization of a new endo-type polyM-specific alginate lyase from Pseudomonas sp. Biotechnol. Lett. 2015, 37, 409-415. [CrossRef]

29. Iwamoto, Y.; Araki, R.; Iriyama, K.-I.; Oda, T.; Fukuda, H.; Hayashida, S.; Muramatsu, T. Purification and characterization of bifunctional alginate lyase from Alteromonas sp. strain no. 272 and its action on saturated oligomeric substrates. Biosci. Biotechnol. Biochem. 2001, 65, 133-142. [CrossRef]

30. Lee, S.; Choi, S.H.; Lee, E.Y.; Kim, H.S. Molecular cloning, purification, and characterization of a novel polyMG-specific alginate lyase responsible for alginate MG block degradation in Stenotrophomas maltophilia KJ-2. Appl. Microbiol. Biotechnol. 2012, 95, 1643-1653. [CrossRef]

31. Yagi, H.; Fujise, A.; Itabashi, N.; Ohshiro, T. Purification and characterization of a novel alginate lyase from the marine bacterium Cobetia sp. NAP1 isolated from brown algae. Biosci. Biotechnol. Biochem. 2016, 80, 2338-2346. [CrossRef] [PubMed]

32. Miyazaki, M.; Obata, J.; Iwamoto, Y.; Oda, T.; Muramatsu, T. Calcium-sensitive extracellular poly ( $\alpha$-L-guluronate) lyase from a marine bacterium Pseudomonas sp. strain F6: Purification and some properties. Fish. Sci. 2001, 67, 956-964. [CrossRef]

33. Zhang, Y.-H.; Shao, Y.; Jiao, C.; Yang, Q.-M.; Weng, H.-F.; Xiao, A.-F. Characterization and application of an alginate lyase, aly1281 from marine bacterium Pseudoalteromonas carrageenovora ASY5. Mar. Drugs 2020, $18,95$. [CrossRef]

34. Yang, M.; Yu, Y.; Yang, S.; Shi, X.; Mou, H.; Li, L. Expression and characterization of a new polyG-specific alginate lyase from marine bacterium Microbulbifer sp. Q7. Front. Microbiol. 2018, 9, 2894. [CrossRef] [PubMed]

35. Zhou, R.; Shi, X.; Gao, Y.; Cai, N.; Jiang, Z.; Xu, X. Anti-inflammatory activity of guluronate oligosaccharides obtained by oxidative degradation from alginate in lipopolysaccharide-activated murine macrophage RAW 264.7 cells. J. Agric. Food Chem. 2015, 63, 160-168. [CrossRef] [PubMed]

36. Powell, L.C.; Pritchard, M.F.; Emanuel, C.; Onsoyen, E.; Rye, P.D.; Wright, C.J.; Thomas, D.W. A nanoscale characterization of the interaction of a novel alginate oligomer with the cell surface and motility of Pseudomonas aeruginosa. Am. J. Respir. Cell Mol. Biol. 2014, 50, 483-492. [CrossRef] 
37. Bradford, M.M. A rapid and sensitive method for the quantitation of microgram quantities of protein utilizing the principle of protein-dye binding. Anal. Biochem. 1976, 72, 248-254. [CrossRef]

38. Miller, G.L. Use of dinitrosalicylic acid reagent for determination of reducing sugar. Anal. Chem. 1959, 31, 426-428. [CrossRef]

(C) 2020 by the authors. Licensee MDPI, Basel, Switzerland. This article is an open access article distributed under the terms and conditions of the Creative Commons Attribution (CC BY) license (http://creativecommons.org/licenses/by/4.0/). 